\title{
Bread: From grain to life. Validating the use of metaphor
}

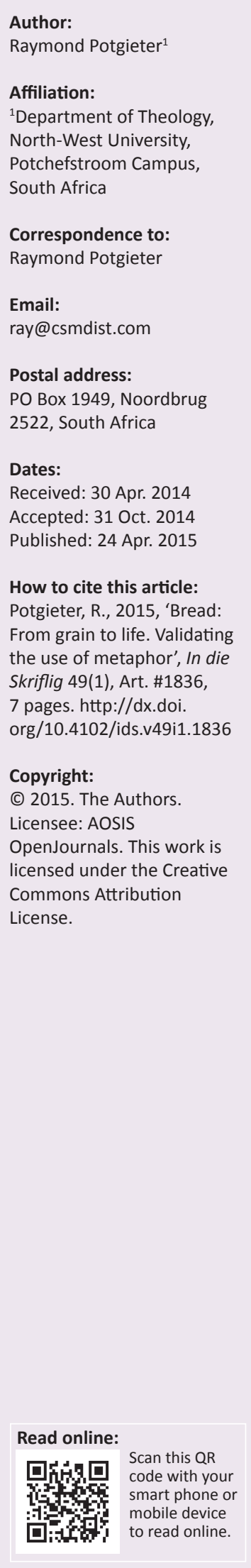

Metaphors have always lent strength to human communication. A closer examination will reveal their value for theological conversation, in particular as a vehicle for meaning. Meaning includes both linguistic and cognitive aspects. Bread has been a favourite subject of metaphor. When the concept bread is viewed metaphorically in the context of the Bible, it becomes evident that it transcends the usual boundaries set by metaphorical understanding. Bread, as metaphor, becomes a vehicle of transition from grain to spiritual life. This is possible because metaphor in the Bible is to be understood within the context of special revelation of God, the story of the Bible.

Brood: Van graan tot lewe. Bevestiging van die gebruik van die metafoor. Metafore versterk kommunikasie tussen mense. Nadere ondersoek openbaar die waarde van metafore vir teologiese gesprek, en in besonder as 'n spreekbuis vir betekenis. Betekenis sluit taalkundige sowel as kognitiewe aspekte in. Brood is 'n algemene begrip wat in metafore gebruik word. Wanneer die begrip brood metafories in bybelse konteks gebruik word, oortref dit gewoonlik die gewone gebruiksbegrensing daarvan. Brood as metafoor kan ook gesien word as die oorgangsmedium van graan tot geestelike lewe omdat metafore in die Bybel binne die konteks van 'n spesiale openbaring van God verstaan moet word - die storie van die Bybel.

\section{Introduction}

The concern of food supply for all led Thomas More (1478-1535), author of Utopia ${ }^{1}$ (1516), to propose common storehouses to supply the collective community according to need and means (More 1922:160). Gandhi recognised that hunger impedes the revelation of God (Van Schooneveld 2010). Bread is, for instance, associated with feeding the masses (cf. Mt 14:13-21).

The story of bread is 'a story more than fifty centuries long' (Barker 1911:5). To know its story is to know something of the story of the world and its industrial and commercial progress (Barker 1911:6), and of enterprising missionaries providing jobs for people (Little 1911). 'Every morning the world wakes up hungry' (Barker 1911:7). Reminiscent of Sirach² 29:21 (Wright 2007:743): 'Life's beginning is water and bread and clothing.' Whilst facing feeding the world's population, substitutes for bread commonly made from wheat or barley, such as 'war bread', was supplied to Caesar's troops (Deutsch 1918). ${ }^{3}$ One of the enduring Roman legacies was the regulated price of bread that continued for centuries (Desportes 2000:201). Bread rations in Constantinople were sometimes made available free of charge for political reasons (Gutsfeld 2003:755).

In the classics, Demeter is poetically linked to mean 'wheat', 'bread' or 'staple food'. Augustus had a predilection for brown bread (Dalby 2003:79, 38) and both Athens and Rome sometimes distributed bread as charitable acts (Dalby 2003:268). Food played a role in Plutarch's Dinner of the Seven Wise Men. ${ }^{4}$ Conversations over dinner included topics that ranged from entertaining with food and wine, and such mundane matters as seating arrangements (Dalby 2003:264).

Its importance for daily sustenance is referred to in Leviticus 26:26 and famine was sometimes the consequence of a lack of bread (Ezk 5:16). The 'breadwinner' association, obvious as the effort to supply food, is directly related to sustaining and survival. ${ }^{5}$ Wheat may lie behind bread, but, as

\footnotetext{
1.Utopia derived as a Greek pun - ou-topos [no place] and eu-topos [good place].

2.Also known as Ecclesiasticus (Vulgate), Wisdom of Joshua (Jesus), Ben Sira (Hebrew), Sirach (Jewish-Greek scriptures) (Wright 2007:715)

3.Also called panis militaris [army bread] (Dalby 2003:61), distinguished from Taylor's War Bread (1918).

4.It is believed that this work is one of historical fiction.

5.See for instance the story of the 'missionary bread' that Florence Nightingale supplied for the welfare of her patients during the
} Crimean War at Scutari (Little 1911). 
Charles Darwin theorised, the origins of gathering, storing and sowing may be related to animal behaviour ${ }^{6}$ (Jacob 2007:1-3).

Because of this naturalness of common experience of hunger and eating, their absorption into religion permeates community and culture. Whether 'hunger' and 'eating' are materially interpreted or interwoven with the sacred, its influences may clearly be brought together in the narrative of choice. ${ }^{7}$ One of the most powerful tools available to religious conversation is metaphor.

Cheung and Cheung (2008) showed that associating participants in creative advertising with the concept of 'bread is life' led to 'a kind of meaning making'. On the other hand, Kovelman and Gershowitz (2012:143-144, 163) show how the biblical interplay between dual opposites ta'aniyot [suffering, fasting] and simkhah [gladness], GodIsrael and God-humankind - expose relationships with deity in meta-history. To that end, metaphor ${ }^{8}$ has been identified as a useful way in which religious language may portray relationship and meaning when speaking about the unknown.

This article will deal with the concept of bread, showing the usefulness of metaphor as a means to convey meaning within the context of biblical revelation. Then, the enduring underlying meaning of the bread metaphor as a means to life will be discussed. This approach may be suggestive of a framework for the study of other biblical metaphors. This article will not deal with the sacramental implications of the use of bread, but will rather focus on the meaning conveyed through the metaphorical use and experience associated with bread.

\section{Usefulness of metaphor for transmission of religious knowledge \\ Explaining metaphor}

A useful analysis of the definition of metaphor ${ }^{9}$ is provided by Hayes and Grundt (1997):

Metaphor comes from the Greek meta, which has to do with sharing, common action or pursuit, or change, and pherein, meaning to carry or transfer. The sharing or transfer of meaning is from a secondary subject called the vehicle, to a principal or primary subject usually called the topic. The shared ground of the metaphor includes those qualities of the topic and vehicle that together form the essence of the figurative interpretation. (p. 136)

6.Charles Darwin read Gideon Lincecum's paper to the Linnaean Society of London dated 13 April 1861 (cf. Jacob 2007:1-3).

7.To this end, Frame (1987:240) says: 'Language is, I maintain, an indispensable element of the image of God in which we are created.' It is thus a tool that may be applied when speaking about God and the metaphysical.

8.The same may be said of, for instance, symbol or hymnody. McFague (1982:15) regards parables as metaphorical thinking.

9.As Hausman (1989:22 \& footnote 12) comments, the task of reviewing the literature dealing with metaphor would be enormous. In actual fact, it is unnecessary, because this has been adequately done by others already. The traditional definition of metaphor given by Aristotle (n.d. Poet. 28.21) is, 'Metaphor is the application of an alien name by transference.'
Meaningfulness accompanies communal conversation, because it provides a frame within which to express religious experience; it objectivises the religious world (Sztajer n.d.:54). A different example would be, for instance, the choice of metaphor in biology. The metaphor chosen would probably be organic, one to describe the dynamics of growth and of development. Conversation would then be based on different presuppositions (Scholnick 1994:254).

\section{Metaphor, religion and theology}

'It is remarkable how much human language is composed of metaphors [...] metaphor provides a means to establish complexity even when the events themselves have no simple referent' (Hayes \& Grundt 1997:140). ${ }^{10}$ A holistic account of humankind must also address the subjective. This includes categories such as 'enjoyment' and 'contemplation', both of which impact upon the intellect and the capacity to imagine; the former regards truth, the latter meaning (Macky 1981:243). Reality's complexity necessitates language-games. Hence, metaphor 'is the way to speak of supersensible human experiences' (Macky 1981:246). This implies that it expresses sacral reality within the experiential categories of religion - a way of thinking.

The particular language usage of metaphor may be charted into theology with its models and concepts (McFague 1982:15, 193) to symbiotically serve to enhance contextual religious understanding and experience. Meaning is possible when the universe is viewed as sacred structure (Ricoeur 1976:62): the context of religion. For that reason every society must be regarded as being infected by religious communication ${ }^{11}$ not least Christian God-talk.

Within this societal transference of knowledge and framework of conversation, McFague (1982:15) suggests a simple anchoring definition ${ }^{12}$ useful for her metaphorical theology: ' $[A]$ metaphor is seeing one thing as something else.' The key to this definition lies in the seeing, translated as transference. She explains: " $[P]$ retending "this" is "that" because we do not know how to think or talk about "this" so we use "that" as a way of saying something about it.' Put differently, the unknown or unfamiliar or incomprehensible is thought of in terms of the known or familiar or comprehensible. McFague's particular take on metaphor is that it reveals tensions used primarily to describe 'relationship', such as God as father or friend..$^{13} \mathrm{~A}$ dominant metaphor like in this instance, may also be supported by additional lesser supportive metaphors. A perception of God as Father will

10.This article will not examine Kuhn's argument (1996) that paradigms exemplify changing packages of (scientific) knowledge.

11.Ricoeur (1976:51ff.) maps the route in which metaphor enters, wanes, recovers and develops, and is distinguished from root metaphors already present in society.

12.Metaphor maps refers to a way to transfer properties from the known source to the unknown target domain so as to enhance the understanding of what meaning is conveyed (Okafor 2014:53-54).

13.The implication is obvious: there are many models of God and more may be created (McFague 1982). 
influence how we think or speak about God and react to that knowledge (Voss 1995:26). ${ }^{14}$

However, metaphor is more than a rhetorical instrument negotiating objective similarity, according to Lakoff and Johnson (1980). Their premise is that the human conception is a metaphorically based system. They shifted metaphor from the language realm into that of cognition. ${ }^{15}$ Both experience and interpretation jointly serve an interpretive role. '[M]etaphor is pervasive in everyday life, not just in language, but in thought and action' (Lakoff \& Johnson 1980:3). Mapping, in this manner, pervades culture, ritual, aesthetic experience and so on. It may include a multiplicity of metaphors to make reality's complexities more apprehensible (Lakoff \& Johnson 1980:18, 19, 23, 239).

Soskice (1987) follows suit in theology. She does not confine metaphor to the system of language alone; it must relate to existing reality ${ }^{16}$ or result in incomplete understanding and therefore incomplete communication (Soskice 1987:160). An example bringing the polar opposites and reality into play will suffice. To claim that God is Spirit one must take account of unequivocal knowledge, as well as the common myriad of experiences of Jews and Christians (Soskice 1987:154). This blend of contextualising metaphor conveys substantial meaning to our words. This may also be illustrated by the experience of the Catholic bishops. A recent study showed that, by including metaphors in their pastoral letters, the bishops tried, with some success, to establish some understanding of and identify with the religious experience of their people (Okafor 2014:62).

Not all theologians would agree with the view that metaphor serves as fons et origo [source and origin] of meaning. Clark's (Macky 1981:239) opinion ${ }^{17}$ is that metaphor is ornamental when used to speak about God - 'mere surrogates of the real thing'. Poetic speech of the Bible allowed C.S. Lewis to appreciate a richness of transmission in not only metaphors, but also in parables, analogies, and so on. Progress in theological knowledge, for Lewis (1976:45), assumed that some knowledge, such as the fundamental Christian doctrines, is not superseded. Masson (2004:271) agrees that there must be a reciprocal response to new uses of language relative to humanity and mystery. ${ }^{18}$ This suggests some

14.Voss (1995:26), for instance, understands Soskice's working linguistic definition ('Metaphor is that figure of speech whereby we speak about one thing in terms which are seen to suggestive of another') to be restrictive, even though it includes 'state of a speech is a trope and does not include at her use of 'model' (the dominant metaphor) (McFague 1982:23), which basically equates to 'metaphor', seems to go beyond this limitation.

15.Metaphor, in this sense, expands cognition to include both language understanding as well as knowledge representation - a new perception of how we think.

16.Soskice tries to keep a divide between kataphatic (positive) and apophatic theology (negative). She does not do so to the extent that each develops its own individual theological story. For that reason she is cautious about a postmodern approach that sees language as the embodiment of reality by a system of linguistic signifiers. For instance, the intrinsic value of pedagogical use of metaphor in child education is that it is not just seen as a linguistic device, but involves and shapes meaning making (Taylor 2012:163).

17. His philosophy follows the path of rationalist idealism (Macky 1981:242).

18.For Masson, 'mystery' could be applied generically, and thus equally apply to spirituality and religion. correlation with Ricoeur's 'root metaphors' and McFague's (1982:190ff.) use of the word model. ${ }^{19}$ Whilst metaphor must be contained within the basic context and not exceed its limitations as a model, creative adaptation by feminists show how they may be developed within changing contexts. ${ }^{20}$

In summary, vagueness in scripture is often due to the figurative use of language. Metaphors 'come to our rescue in theology and play roles that are quite central'21 (Frame 1987:226). Whilst they do convey relationship (McFague 1982), transference allows for an advance of complex knowledge (Soskice 1987; Hausman 1989; Lewis 1976; Lakoff \& Johnson 1980) and so dynamically influence thought and act. These insights allow for the exploration of bread as a Christian metaphor.

\section{Introducing bread as a religious metaphor}

Bread in the cultural and/or religious narrative of most communities, in time, tended to develop tendencies towards complementary metanarratives. ${ }^{22}$ The complexity of the subject includes its role in religion to conclude that, whatever the understanding of metaphor, 'one cannot speak of God without using metaphor ${ }^{\prime 23}$ (DesCamp \& Sweetser 2005:236). A drawback is the inordinate attention paid to the use of masculine metaphors when simply located in linguistics. It is when the structures of human thought, suggested by cognitive linguistics, are taken into account that this aspect is addressed.

More specifically, Christian metaphor must therefore be seen within the context and limits of its Judaeo-Christian origin and experience. Whilst the tool for discussion may be biblical metaphor, the content of that knowledge is given by God as revelation to humankind within the framework of experience. ${ }^{24}$ Frame $(1987: 1)^{25}$ believes that incomprehensible God may, to an extent, be made comprehensible through

19. For McFague there is not one overarching root-metaphor in Christianity. Rather, the variety of metaphors illumines the complex relationship with God.

20.Though substantial feminine imagery is lacking in the Bible and Christian tradition, McFague (1982:167), for instance, has no problem in developing the relationship between human beings and God using various models (feminine metaphors) as possibilities for liberating women.

21.Frame (1987:226-227) refers to the federal headship of Adam as the representative (cursive inserted to draw attention to the metaphor) of the human race, juxtaposed to the representation of Christ to his redeemed (cf. Rm 5:12ff.).The usefulness lies in immediate comparison and contrast made possible by the use of metaphor.

22. Heelas (2007:270-271), who claims to be a modernist, suggests that postmodernism comprises of either a metanarrative or multiple metanarratives, and suggests an integrative or middle way. There is also doubt that a metanarrative could possibly suffice for all there is to know (Lyotard 1984) and so Lyotard suggests could possibly suffice for all there is to know (Lyotard 1984) and so
that it may be replaced with petit récits [small narratives/stories].

23.Nor can one speak about living without resorting to metaphor. According to Lakoff and Johnson (1980:19), the intuitive identification and interpretation of metaphors depends on how well the metaphors relate to or fit experiences. A viewpoint of marriage as a 'tie', 'team' or 'sacrament', or of daily living in terms of 'time is money', 'problems are puzzles' (Lakoff \& Johnson 1980:239) will carry with it a different set of expectations for each perspective. Metaphor, in this sense, becomes something that structures everyday living, influencing our very acts and thoughts to create realities (Lakoff \& Johnson 1980:156).

24.Lakoff and Johnson (1980:239) suggest that metaphors are further extended by considering other cultures and so seeing beyond the 'truths' of a single culture, using known metaphors to explore other metaphors.

25.God may be known in his 'relations to the world and to many things in the world, especially ourselves' (Frame 1987:9-100, 9). 
reason, revelation, tradition, sacraments, and so on. Possible because not all language about God is figurative (Frame 1987:226), allowing for community conversation and, by implication, experiencing God. Within the biblical social ambit, metaphor serves as a useful cognitive tool by which comprehensive knowledge of God may be gleaned through the exploration of substitution, metaphysical extrapolations and experience. Association beyond the pages of the Bible could, for instance, apply metaphor ${ }^{26}$ to moral propriety, which may be traced to conceptual structures that came about 'from our experiences with dirt and cleanliness' (Lizardo 2012:385). The same may be deduced about bread when filtered through the sacred categories of communities not least because metaphor is so deeply ingrained in human psyche and the culture of human communities. Some metaphors have fallen into disuse. The associated sexual connotations of the oven metaphor of Hosea 7:4 has abused this metaphor so that it is no longer popular today to speak of 'a bun in the oven'27 (Rowland 1970).

Some cautionary remarks from Frame (1987:228-232) are appropriate when resorting to and applying metaphor. In this, these premises may also be applicable to most religions in which metaphor is employed for meaning and understanding:

- Metaphor does not apply to every context.

- They must not be pressed for less obvious meaning.

- Metaphor is not a tool to introduce abstraction as nonabstraction.

- Metaphor is never to identify God with anything. ${ }^{28}$

- Language about God need not be qualified by metaphor in every instance.

- Use of metaphors must be consistent with overall biblical revelation.

\section{'Eat! I am the bread'29 The representative use of bread}

Amongst others, bread has taken on representative symbolic meaning. This article will not explore the intricacies of the variety of meanings for ritualistic use and its symbolism ${ }^{30}$ such as Petocz (1999) does in relation to psychoanalysis. This article accepts the premise of living in a symbol system (Clift \& Clift 1991:28) encoded with information, ${ }^{31}$ which influences

26. Even though there sometimes is confusion discerning between metaphor simile symbol, analogy, model and so on, I do not wish to spend time defining these on the use of metaphor. For extensive (1987). The meaning and use of for instance symbol proves equally complex (cf. Petocz 1999).

27.Implying being pregnant.

28.Erickson (2013:80) suggests that 'language teaching is an inadequate metaphor'. For instance in the context of all of revelation to see a statement such as 'God is high above the earth' must be understood in terms of God's transcendence giving expression to that truth about God which pervades scripture and is conveyed by the metaphor.

29.Jacob (2007:17).

30.Petocz (1999), for instance, explores symbol in a broad continuum only to narrow it down so as to establish bona fides of its relational application for psychoanalysis, but it must be borne in mind that metaphor encapsulates most of symbol.

31. Historically language was equated to speech, but it is 'comprehension, not speech, (that) is the foundation of language' (Rumbaugh \& Savage-Rumbaugh 1997:150). social behaviour and complex behavioural communication at all levels (Rumbaugh \& Savage-Rumbaugh 1997:150-151; Hayes \& Grundt 1997:142). Jacob (2007:17), referring to bread, says: 'The Egyptians who invented it, ${ }^{32}$ based their entire administrative system upon it; the Jews made bread the starting point of their religious and social laws.'

Bread and wine together distinguished a community from a 'barbaric lifestyle' and played an integral part in religious offerings and commemorations (Gutsfeld 2003:755). This latter significance of bread reached its high point on the day when Jesus Christ made consummate the spiritual significance that had become attached to it, saying, 'Eat! I am the bread' ${ }^{33}$ Implicit to that meaningful, concrete and identifiable substance of bread was the verbal and intellectual comprehension of meanings beyond those of taste, smell and feel. A cognitive apprehension was also present when Jesus made that personalised statement. This is where the corpus of Judaeo-Christian religious tradition of revelation, which served to authenticate this high point of metaphoric expression, came into play.

\section{The Father/Provider God and bread}

McFague (1982) established that relationship with God is implied in the structure and source domain of metaphor at a dominant level of religious language. ${ }^{34}$ Illustrative of this dominance would be the fatherhood of God, suggestive of relational interplay; father-son (DesCamp \& Sweetser 2005). However, this motif may also be developed with juxtaposed positive or negative connotations expressed as: ' $[B]$ oth trust and rebellion, love and resentment from the parent-child space into the God-human space' (DesCamp \& Sweetser 2005:236). It is this generic structure that this article will use to explore the spiritual connotation of bread in the relationship of God with humans and humans with God.

Whereas the fatherhood of God is evident in the term Father God, it is also implicit in the metaphor LORD Provider (Yahweh Provider). ${ }^{35}$ Not only does God associate himself with the use of bread in the present, he also changes the recipe (Ex 12:8). This has lasting significance - unrelated, for instance, in this sense - to geography (Ex 12:20,24), though non-adherence to the recipe signified banishment from God's people (Ex 12:15).

Suggestive that God as Father is the source of provision or supply, ${ }^{36}$ Israel learnt to obey God with regard to abhorrence

32.Jacob (2007:18ff.) discusses the discovery of baking as a process.

33.It will become clear that the phrase used, brings together the statements of Jesus in Matthew 26:26, its significance at the last supper, and John 6:35 and the significance of Jesus, who is the bread for the masses.

34.Within the interplay process there is loss and gain, to the extent that precision and consistency are sacrificed for richness gained in greater meaning (McFague 1982:26). Choice of a dominant metaphor, which supposedly orders with increased complexity, seems to be overly dependent on the researcher's perspective of interpretation such as that due to advances of feminist theory and sociological studies (McFague 1982:145-192).

35.Cf. Genesis 22:14 (Yahweh; jireh).

36.Whilst the Bible does embroider on the metaphor of bread, this study will mainly focus on the Passover and the journey through the desert, particularly from Exodus 12 and 16. These passages should adequately serve to make the point of the development of bread as metaphor, later elevated to its highest expression by Jesus (Jn 6:35). 
for leaven in bread. This applied only to particular occasions such as the Passover feast (Ex 12:8), which developed into the Feast of the Unleavened Bread ${ }^{37}$ (Ex 12:17). Implicit in this relationship of God as Supplier and/or Provider and needy persons, a duality is found: that of adequacy and inadequacy, life or death (in relation to the explicit revealed meaning related to the substance provided). This metaphor developed out of necessity as Israel's journey led them through the desert, toward a land where bread (lechem, artos, sitos, panis) would not be in short supply (Dt 8:9). Food, as a necessity for survival, became an issue on this journey. Moses pointed to the leadership of God, whose choice of route brought them out of Egypt into the desert. A consequence of the desert experience brought out another duality associated with food and/or bread: the failure to trust God as food supplies dwindled, leading to rebellion by the people (Ex 16:2). When supplicated, Supplier God supplied a 'rain' [matar] of manna. Though supplied from heaven, it is in the form of recognisable fare, most easily associated with bread (lechem/ food) (Ex 16:15). God is clearly seen in relationship with his people who experience their need provided for. God is the supplier of bread and/or food, available to all.

Hence, the metaphor allows for an implicit suggestion: God Provider, located in heaven, provides food/bread from that location, so that this bread (lechem) is significantly understood as the bread/manna (mawn) 'from heaven/God'. God Provider may indeed be trusted to supply and provide. However, deity purposefully invading creation and human space is not without risk. Though the food is gratefully accepted at first and regarded as adequate, the repetitive supply leads to the polar opposite reaction of inadequacy. This dual response of the people to Provider God may be expressed as grateful or ungrateful - a consequence of adequate or inadequate. Whilst the first duality suggests attitude, the second suggests assessment. More dualist responses may of course be identified: thankfulness or resentment, expectation or demand, and so on. A view of God Provider from heaven is mapped in terms of an invasion of human space occupied by dependents desperate for sustenance, even fearing life's end if provision was not forthcoming. This is significant, because metaphor relates to human cognition ${ }^{38}$ - bread takes on meaning within the communal mind and shapes thinking.

Cognitively, this substantiates the argument that, within sacral space, without bread there is no life - whether physical or spiritual. By implication then, when God meaningfully invades known human space and geography with supply for survival as in the desert, it is more than relationship. It was a way of thinking and understanding, made possible because of the God-origin of life within the sacral structure of creation. This excursion to establish bread as metaphor is

37.This feast lasted for seven days, whilst the Passover feast is only a day and night the first 24-hour period of the seven-day period. In Homeric times, bread was regarded as a luxury and the common people ate the earlier stages of bread, for instance the barley pancake (mâza) (Gutsfeld 2003:755).

38.Erickson (2013:80) suggests that 'language teaching is an inadequate metaphor', for instance, in the context of all of revelation to see a statement such as 'God is high above the earth', must be understood in terms of God's transcendence giving expression to that truth about God, which pervades Scripture and is conveyed by the metaphor. deemed adequate, but may clearly be refined and developed in the ongoing Judaeo history. ${ }^{39}$

\section{'Jesus Bread' - Life in human space}

Whilst DesCamp and Sweetser (2005:234) suggest that the two 'richest and most complex', hence the most powerful, metaphors are 'father' and 'king', this article would like to suggest that the metaphor of 'bread' should be considered the most powerful metaphor for sustaining life in human space.

The understanding of the Gospel of John is enhanced through rhetorical tools, such as synkrisis ${ }^{40}$ and associate synkritic language (Myers 2012:19). Readers of the Gospel, who meet with the Logos, are supposedly familiar with the corpus of Mosaic writings and the stature of Moses. Consequently, they do not face a choice of allegiance. Rather, 'both men $^{41}$ [are] complementary actors in God's overarching plan for redemption' (Myers 2012:20). In this way Myers thus establishes the link between the content of the Mosaic corpus (Old Testament) and the Gospel of John (New Testament). As Jesus is not compared to Moses (Ex 17:1-6; Nm 20:2-13), but to the rock from which the superior water of John 6:35 issues (Myers 2012:17). So by implication, the manna, the bread that rained from heaven (Ex 16:4), is suggestive of the superior bread of John 6:35. Myers (2012:16-20) establishes that the Logos (Jesus) is the one of whom Moses wrote. However, this Logos transcends the fullness of Mosaic proto-theological meaning, which, by implication, could not be fully captured in the form of common God-talk until the revelation of the incarnation of the Logos.

In a sacred universe, life is not regarded as located here and there; it is one permeated or pregnant with life everywhere when viewed from the perspective of the sacral. Because symbol is inextricably interwoven with the universe, metaphor becomes the 'free invention of discourse' (Ricoeur 1976:61), that is, the possibility of the fullness of cognition and communication. With this Ricoeur establishes the emergence of the possibility of a theme, providing for the implicit and explicit superiority of bread. For that reason, when Jesus personalised the metaphor of 'Bread of life' (Jn 6:35, 48), the association spanned Jewish history and, by implication, included all who are presently hunger ${ }^{42}-$ be it physical or spiritual. ${ }^{43}$

39.There is also a dark side to the bread metaphor. It is, amongst others, associated with wickedness (resha), used as a metaphor for idleness (Pr 31:27). This will not be explored in this article.

40.This term 'refers to the comparative juxtapositioning of people and things' (Gärtner 2014). Ancient writers took for granted knowledge of myths and legends, whilst the apostle John assumed comparative knowledge of the corpus of Mosaic writings for his account of Jesus (Myers 2012).

41.That is Jesus and Moses.

42.There are many themes associated with bread that may be explored, such as generosity in the midst of poverty, hospitality in a broader sense and deception (cf. Jos 9:12), communal centering of fellowship around meals (Rt $2: 14$ ), miraculous incidents including bread (1 Ki 17:12ff.). Only those deemed appropriate for this article were selected.

43.This obviously transcends the view that Christian religion is an epiphenomenon of evolution rather than of revelation. 
The physical mawn of the Old Testament and the artos of the day are historically representative of the bread that fed humankind for generations, and that continues to do so. It was the same or similar common bread or food that Jesus had in his hands at the Last Supper (cf. Mt 26:26). Famine, whether physical or spiritual, is not relieved by tales of past bounty or by prophecies of plenty to come. Jesus did not say, 'There is a bread of life.' He said: 'I am the bread of life.' The former would send one on a search for that bread and the latter would settle matters upon finding Jesus, taking him at his word. For that instant in history, Jesus was the bread supplied and physically present. Wilken (1995:166) concludes that faith is as good as its object and in this instance Jesus Bread was mapped as occupying human cognitive space.

At the last supper, the issue was not simply physical sustentation and survival in the face of opposition, but the invasive presence of a visible bread to be eaten. Because Old Testament faith was preoccupied with God, Jesus adjusted the disciples' understanding towards a fuller meaning of messianic understanding (Lk 22:14-23). The metaphor allows for God's provision to serve as an invasion of the worship of his church. Without Jesus, feeding the whole person there cannot be true worship of God (1 Cor 11:27ff.). He is Jesus Bread in the same sense that God may legitimately be called Father God, ${ }^{44}$ and is in this manner the shared cognitive apprehension of the Christian church. The metaphor allows the church to see Jesus as bread to be partaken of as food for life, whilst at once revealing its limitations in the symbolic practise thereof. This is evident in the following example.

How did Peter Martyr Vermigli (1499-1562) deal with 'revelation [that] exists as a body of free-floating truths?' (Soskice 1987:154). Because Christianity is 'a religion of the book' (Soskice 1987:154), he struggled to define the sacramental association with the elements (Avis 1999:11ff.). Martyr spoke of eating two kinds of bread at the Lord's Supper $^{45}$ (Vermigli 1994):

The reception of Christ's body that we have by faith is called a metaphorical eating $[\ldots]$ we also have an authentic eating of the symbols, just as bread is both true and natural. (p. 220)

However, this act of participation in the breaking of bread, in agreement with Bucer, is not crucifying Christ anew (Vermigli 1994:223). Indeed, the bread, when made sacrament, carries within it the change associated with accompanying symbols at its sacramental consecration (Vermigli 1994:275, 276). From this statement it must be assumed that Vermigli shifted the emphasis from Jesus as bread to the meaning of bread. This flies in the face of later theological realism, which concerns

44.This article does not, for instance, explore the love relationship of the church and Jesus (cf. Wilken 1995:165-166). The author also accepts the differences regarding the messianic expectations that, for instance, may have been as simple as awaiting a day when the new 'golden age' would be ushered in (cf. Klauser 1955:57 footnote 51 in Wilken 1995:112).

45.This is not in the veridical sense implying a mimetic representation of reality, but rather a mixture between the imaginative and an apprehension of truth. itself with metaphor as 'conceptual possibility rather than proof' (Soskice 1987:148) - justifying the validity to speak of God and metaphysical matters as addressed to worshippers. These were matters that found substantial expression beyond the usual use of linguistic metaphor, which were addressed during the reformation and formulated in reformed confessions and catechisms that endure today (Potgieter 2013).

\section{Conclusion}

When the Christian Church presents Jesus Bread, the issue is whether the people are fed or not. People face the inevitable conclusion that 'this physical bread will not sustain me forever'. It therefore gives rise to the eternal quest for some bread or food, or in 3rd millennium language: some drug, some surrogate, or some medical breakthrough that will ensure my existence and quality of life for aeons to come. The metaphor of bread, developed as Jesus Bread just as Father God developed in time, focuses the attention upon the remedy for human plight: 'Eat and live forever'. Metaphor validates the truth that God invades human cognition and that substantial meaning may be gleaned from it when found within the context of biblical revelation.

\section{References}

Aristotle, n.d., The poetics of Aristotle (The Electronic Classics Series), transl. S.H. Butcher, Pennsylvania State University, Hazleton, viewed 26 February 2014, from http://www2.hn.psu.edu/faculty/jmanis/aristotl/poetics.pdf

Avis, P.D.L., 1999, God and the creative imagination: Metaphor, symbol and myth in religion and theology, Routledge, London/New York. http://dx.doi. org/10.4324/9780203279373

Barker, E.L., 1911, The story of bread, International Harvester Company, Chicago. http://dx.doi.org/10.5962/bhl.title.25970

Cheung, M. \& Cheung, C., 2008, 'The metaphor of "Bread is Life": A semiotic analysis of visual representation in print advertisement designs', paper presented at the annual meeting of the International Communication Association, TBA, Montreal, Canada, May 22, viewed 21 February 2014, from http://citation.allacademic.com/ meta/p232941_index.html

Clift, J. \& Clift, W.B., 1991, The hero journey in dreams, Crossroad Pub, Belleville.

Dalby, A., 2003, Food in the ancient world: From A to Z, Routledge, London.

DesCamp, M.T. \& Sweetser, E.E., 2005, 'Metaphors for God: Why and how do our choices matter for humans? The application of contemporary cognitive linguistics research to the debate on God and metaphor', Pastoral Psychology 53(3), 207238. http://dx.doi.org/10.1007/s11089-004-0554-5

Desportes, F., 2000, 'Bread', in A. Vauchez (ed.), Encyclopedia of the Middle Ages, vol. 1 (A-J), pp. 200-201, James Clarke, Cambridge.

Deutsch, M.E., 1918, 'Roman war bread', The Classical Journal 13(7), 527-528, viewed 22 February 2014, from https://archive.org/details/jstor-3287908

Erickson, M.J., 2013, Christian theology, 3rd edn., Baker Academic, Grand Rapids.

Frame, J.M., 1987, The doctrine of the knowledge of God, Presbyterian and Reformed Publishing Company, Phillipsburg.

Gärtner, H.A., 2014, 'Synkrisis', in H. Cancik \& H. Schneider (eds.), Brill's New Pauly: Antiquity volumes (Brill Online Reference Works), viewed 25 February 2014, from http://referenceworks.brillonline.com/entries/brill-s-new-pauly/ synkrisis-e1127330

Gutsfeld, A., 2003, 'Bread', in H. Cancik \& H. Schneider (eds.), Brill's New Pauly: Encyclopaedia of the ancient world (Antiquity), vol. 2, pp. 754-755, Koninklijke Brill NV, Leiden.

Hausman, C.R., 1989, Metaphor and art: Interactionism and reference in the verbal and nonverbal arts, Cambridge University Press, Cambridge.

Hayes, S.C. \& Grundt, A.M., 1997, 'Metaphor, meaning and relational frame theory', in C. Mandell \& A. McCabe (eds.), Psychology, the problem of meaning: Behavioural and cognitive perspectives, pp. 117-146, Elsevier Science B.V., North Holland. and cognitive perspectives, pp. 117-146, Elsevier
$\mathrm{http}: / / \mathrm{dx}$.doi.org/10.1016/S0166-4115(97)80135-5

Heelas, P., 2007, 'Postmodernism', in J.R. Hinnels (ed.), The Routledge Companion to the study of religion, pp. 259-274, Routledge, London.

Jacob, H.E., 2007, Six thousand years of bread: Its holy and unholy history, Skyhorse publishing, New York.

Klauser, T., 1955, The messianic idea in Israel from its beginning to the completion of the Mishnah, Macmillan, New York. 
Kovelman, A. \& Gershowitz, U., 2012, 'The Talmud's pharmacy: The metaphors of "Taanit", in A.J. Avery-Peck (ed.), The Review of Rabbinic Judaism,
Ancient, Medieval and Modern, pp. 139-164, Brill, Leiden. http://dx.doi. Ancient, Medieval and Modern,
org/10.1163/15700704-12341234

Kuhn, T.S., 1996, The structure of revolutions, 3rd edn., University of Chicago Press, Chicago/London. http://dx.doi.org/10.7208/chicago/9780226458106.001.0001

Lakoff, G. \& Johnson, M., 1980, Metaphors we live by, University of Chicago Press, Chicago.

Lewis, C.S., 1976, God in the dock: Essays on theology and ethics, W.B. Eerdmans, Grand Rapids.

Little, W.S., 1911, 'Florence Nightingale and missionary bread making', The American Journal of Nursing 11(5), 376-377, viewed 21 February 2014, from http://www. jstor.org/stable/3404993

Lizardo, O., 2012, 'The conceptual bases of metaphor of dirt and cleanliness in mora and non-moral reasoning', Cognitive Linguistics 23(2), 367-393. http://dx.doi. org/10.1515/cog-2012-0011

Lyotard, J-F., 1984, The postmodern condition: A report on knowledge, transl. G. Bennington \& B. Massumi, University of Minnesota Press, Minneapolis.

Macky, P.W., 1981, 'The role of metaphor in Christian thought and experience as understood by Gordon Clark and C.S. Lewis', The Journal of the Evangelical Theological Society 24(3), 239-250.

Masson, R., 2004, 'Saving God', Horizons 31(2), 239-271. http://dx.doi.org/10.1017/ S0360966900001547

McFague, S., 1982, Metaphorical theology: Models of God in religious language, Fortress Press, Minneapolis.

More, T., 1922, Utopia, Cambridge University Press, Cambridge.

Myers, A.D., 2012, 'The One of whom Moses wrote', in C.A. Evans \& H.D. Zacharias (eds.), What does the scripture say? Studies in the function of scripture in Early Judaism and Christianity, vol. 2, pp. 1-20, T\&T Clark, London/New York.

Okafor, V.C., 2014, 'Metaphor as a rhetorical tool in selected Roman Catholic bishops' pastoral letters in Onitsha ecclesiastical province, Nigeria', American Internationa Journal of Contemporary Research 4(2), 53-63.

Petocz, A., 1999, Freud, psychoanalysis, and symbolism, Cambridge University Press, Cambridge. http://dx.doi.org/10.1017/CBO9780511583452
Potgieter R., 2013, 'A confident call to faith: Rediscovering the relevance of Christian catechisms', In die Skriflig/In Luce Verbi 47(2), Art. \#686, 10 pages.

Ricoeur, P., 1976, Interpretation theory: Discourse and the surplus of meaning, Christian University Press, Fort Worth, Texas.

Rowland, B., 1970, 'The oven in popular metaphor from Hosea to the present day', American Speech 45 (3-4), 215-222. http://dx.doi.org/10.2307/454836

Rumbaugh, D.M. \& Savage-Rumbaugh, E.S., 1997, 'A comparative perspective on the etiology of meaning and assaying behaviors for meaning', in C. Mandell \& A. McCabe (eds.), Psychology, the problem of meaning: Behavioural and cognitive perspectives, pp. 147-180, Elsevier Science B.V., North Holland. http://dx.doi. org/10.1016/S0166-4115(97)80136-7

Scholnick, E.K., 1994, 'Route metaphors', Pscychological Inquiry 5(3), 254-256, viewed 25 September 2014, from Stable URL: http://www.jstor.org/stable/1448862

Soskice, J.M., 1987, Metaphor and religious language, Clarendon Press, Oxford.

Sztajer, S. n.d., 'How is religious discourse possible? The constitutive role of metaphors in religious discourse', pp. 49-54, viewed 09 April 2014, from http://www. gobookee.org/religious-discourse/

Taylor, A.E., 1918, War Bread, The MacMillan Company, New York.

Taylor, R., 2012, 'Messing about with metaphor: Multimodal aspects to children's creative meaning making', Literacy 46(3), 156-166. http://dx.doi.org/10.1111/ j.1741-4369.2012.00658.x

Van Schooneveld, A., 2010, 'God in the form of bread', Relevant Magazine, 26 May, viewed 21 February 2014, from http://www.relevantmagazine.com/taxonomy/ viewed 21 rerm/22428

Vermigli, P.M., 1994, The Oxford treatise and disputation on the eucharist 1549, transl. J.C. McLelland, vol. 56 (Sixteenth century essays \& studies), Sheridan Books, Chelsea/Michigan.

Voss, S, 1995, What number is God? Metaphors, metaphysics, metamathematics, and the nature of things, State University of New York Press, Albany.

Wilken, R.L., 1995, Remembering the Christian past, Eerdmans, Grand Rapids.

Wright, B.G., 2007, 'Wisdom of lesous son of Sirach', in A. Pietersma \& B.G. Wright (eds.), A new English translation of the Septuagint (N.E.T.S.): A new translation of the Greek into contemporary English - An essential resource for biblical studies, pp. 715-762, Oxford University Press, New York. 